\title{
$\mathrm{NiSi}$ 접촉과 $\mathrm{Cu}$ 플러그/ $\mathrm{Ti}$ 확산방지층의 동시 형성 연구 \\ 배규식 ${ }^{\dagger}$ \\ 수원대학교 전자재료공학과
}

\section{Simultaneous Formation of NiSi Contact and Cu Plug/Ti Barrier}

\author{
Kyoo-Sik Bae ${ }^{\dagger}$ \\ Department of Electronic Materials Engineering, The University of Suwon, Suwon 445-743, Korea
}

(2010년 6월 14일 접수 : 2010년 6월 18일 최종수정 : 2010년 6월 19일 채택)

\begin{abstract}
As an alternative to the $\mathrm{W}$ plug used in MOSFETs, a Cu plug with a NiSi contact using $\mathrm{Ta} / \mathrm{TaN}$ as a diffusion barrier is currently being considered. Conventionally, $\mathrm{Ni}$ was first deposited and then NiSi was formed, followed by the barrier and $\mathrm{Cu}$ deposition. In this study, $\mathrm{Ti}$ was employed as a barrier material and simultaneous formation of the NiSi contact and $\mathrm{Cu}$ plug / Ti barrier was attempted. $\mathrm{Cu}(100 \mathrm{~nm}) / \mathrm{Ti} / \mathrm{Ni}(20 \mathrm{~nm})$ with varying Ti thicknesses were deposited on a Si substrate and annealed at $4000^{\circ} \mathrm{C}$ for $30 \mathrm{~min}$. For comparison, $\mathrm{Cu} / \mathrm{Ti} / \mathrm{NiSi}$ thin films were also formed by the conventional method. Optical Microscopy (OM), Scanning Probe Microscopy (SPM), X-Ray Diffractometry (XRD), and Auger Electron Microscopy (AES) analysis were performed to characterize the inter-diffusion properties. For a Ti interlayer thicker than $50 \mathrm{~nm}$, the NiSi formation was incomplete, although $\mathrm{Cu}$ diffusion was inhibited by the Ti barrier. For a Ti thickness of $20 \mathrm{~nm}$ and less, an almost stoichiometric NiSi contact along with the $\mathrm{Cu}$ plug and Ti barrier layers was formed. The results were comparable to that formed by the conventional method and showed that this alternative process has potential as a formation process for the $\mathrm{Cu}$ plug/Ti barrier/NiSi contact system.
\end{abstract}

Key words $\mathrm{Cu}$ contact, NiSi, Ti Diffusion barrier, Ti thickness, interdiffusion.

\section{1. 서 론}

고집적 MOSFET 소자의 크기가 $100 \mathrm{~nm}$ 이하로 축소 됨에 따라 다층 배선층의 $\mathrm{RC}$ 지연과 더불어, 텅스텐 $(\mathrm{W})$ 플러그의 높은 비저항 $(9.17 \mu \Omega-\mathrm{cm})$ 과 접촉 저항이 성능 향 상의 걸림돌로 부각되었다. 이에 따라 텅스텐 대신에 비 저항 $(1.67 \mu \Omega-\mathrm{cm})$ 이 낮은 구리 $(\mathrm{Cu})$ 를 플러그 재료로 사 용하려는 노력 ${ }^{1-6)}$ 이 시도되고 있다. $\mathrm{Cu}$ 는 이미 $\mathrm{Al}$ 을 대 체하여 배선 금속으로 사용되고 있어, 소스/드레인의 플 러그 재료로도 적용되면 성능 향상은 물론, 소자 제조 공정을 크게 단순화시킬 수 있다. 한편, $\mathrm{NiSi}$ 는 $\mathrm{TiSi}_{2}$ 나 $\mathrm{CoSi}_{2}$ 에 버금가는 낮은 비저항을 가졌으며, 면저항의 선 폭의존성이 없고, 실리사이드 형성 시 실리콘 소모량이 작은 장점으로 고집적 소자의 소스/드레인의 접촉 및 게 이트 재료로 적용되어 왔다..$^{-8)}$ 그런데, $\mathrm{NiSi}$ 는 $350^{\circ} \mathrm{C}$ 의 저온에서도 형성이 가능한 반면, 고온의 후속 열공정이 있 으면 응집이 일어나거나 고 비저항이 높은 $\mathrm{NiSi}_{2}$ 로 전환

Corresponding author

E-Mail : ksbae@suwon.ac.kr (K. -S. Bae)
하는 열적불안정성으로 인해 높은 누설전류를 야기한다. DRAM의 경우 캐패시터 유전체 내부와 유전체/전극 계 면의 결함을 줄이기 위해 통상 $750^{\circ} \mathrm{C}$ 에서 열처리한다.) 그러나, 최근에는 고집적 반도체 소자, 특히 $\mathrm{CMOS}$ 논 리소자의 크기가 $45 \mathrm{~nm}$ 이하로 줄어들면서 후속 열공정 온도가 낮아져 이러한 열적 부담은 감소되고 있다. ${ }^{6,9}$

$\mathrm{Cu}$ 는 $200^{\circ} \mathrm{C}$ 이하에서도 $\mathrm{Si}$ 및 $\mathrm{SiO}_{2}$ 로 확산하고 $\mathrm{Cu}_{3} \mathrm{Si}$ 를 형성하여 소자의 전기적 특성을 저하시키므로 소자 상 층부의 $\mathrm{Cu}$ 배선에는 물론, 기저층의 소스 및 드레인에 서도 $\mathrm{Cu}$ 플러그와 실리사이드사이에 확산방지층이 필요 하다. $\mathrm{Cu} / \mathrm{NiSi}$ 의 경우에도 $350^{\circ} \mathrm{C}$ 이상에서 $\mathrm{Cu}$ 가 확산하 여 $\mathrm{Cu}_{3} \mathrm{Si}$ 를 형성함으로서 누설전류가 증가되는 것으로 보 고되었다. ${ }^{1)}$ 소스/드레인의 확산방지층은 $\mathrm{Cu}$ 확산 방지 뿐 아니라, $\mathrm{Cu}$ /실리사이드의 접착력과 열적안정성을 향상시 켜야 한다. $\mathrm{Cu} / \mathrm{NiSi}$ 의 확산방지층으로는 $\mathrm{Cu}$ 배선층에 사 용되고 있는 $\mathrm{Ta} / \mathrm{TaN}^{3,5)}$ 와 $45 \mathrm{~nm}$ 이하의 소자에 대비하여 $\mathrm{Ru} / \mathrm{TaN}$ 또는 $\mathrm{Ru}^{6}$ ) 등에 대한 연구가 최근에 보고되었다. 한편, Ti은 glue layer로서의 접착력이 우수하고 저가이 며, 후속 공정 및 소자 사용 온도가 고온이 아닌 경우 $\mathrm{Cu}$ 확산방지 특성이 검증된 재료로서, ULSI의 $\mathrm{Cu}$ 배선층 ${ }^{13)}$ 
과 사용 온도가 $300^{\circ} \mathrm{C}$ 이하인 $\mathrm{SAW}$ 소자의 $\mathrm{Cu}$ 전극 ${ }^{12)}$ 의 확산방지층, 그리고 $\mathrm{NiSi}$ 형성시 capping 층르으로 사용된 바 있다.

일반적으로 $\mathrm{Cu}$ /확산방치층 $/ \mathrm{NiSi} / \mathrm{Si}$ 구조는 $\mathrm{Ni}$ 을 $\mathrm{Si}$ 기판 에 증착하고 $\mathrm{NiSi}$ 를 형성한 후 미 반응 $\mathrm{Ni}$ 을 제거하고, 그 위에 확산방치층과 $\mathrm{Cu}$ 플러그를 순차적으로 증착하여 만든다. ${ }^{2-6)}$ 그리고 이 접촉 구조를 열처리하여 열적안정 성 및 전기적 특성을 분석한다. 본 연구에서는 $\mathrm{Ti}$ 을 $\mathrm{Cu}$ 플러그의 확산 방지 재료로 선택하였고, 기존의 방법과 달 리하여 $\mathrm{Si}$ 기판위에 $\mathrm{Ni}, \mathrm{Ti}, \mathrm{Cu}$ 를 차례로 증착한 후 한 번의 열처리로 $\mathrm{NiSi}$ 접촉 및 $\mathrm{Ti}$ 확산방지층과 $\mathrm{Cu}$ 플러 그를 동시에 형성하여 공정 단순화를 시도하였다. 이렇 게 형성한 $\mathrm{Cu} / \mathrm{Ti} / \mathrm{NiSi}$ 구조의 특성을 $\mathrm{AES}$ 깊이 분석을 중심으로 연구하였다. 특별히 $\mathrm{Ti}$ 층의 두께가 $\mathrm{Cu}$ 확산 및 $\mathrm{NiSi}$ 형성에 미치는 영향을 중점적으로 연구하였다.

\section{2. 실험 방법}

비저항이 $1 \sim 30 \Omega \cdot \mathrm{cm}$ 인 4" $\mathrm{p}$ 형 (100) $\mathrm{Si}$ 웨이퍼 기판 을 아세톤, IPA, 증류수로 각각 5 분간 초음파로 유기물을 세척하고, $10 \% \mathrm{HF}$ 수용액으로 10 분 동안 자연산화막을 제거한 후 증류수로 세정하였다. 이 기판위에 $\mathrm{DC}$ 스퍼터 를 이용하여 상온에서 $9 \times 10^{-7} \mathrm{Torr}$ 의 진공도로 $\mathrm{Ni}(20 \mathrm{~nm})$ 을 증착하고 그 위에 $\mathrm{Ti}$ 을 $10 \sim 100 \mathrm{~nm}$ 증착하였다. $\mathrm{Ti}$ 은 $\mathrm{Ar}$ 분위기에서 $\mathrm{DC}$ power $300 \mathrm{~W}$, 공정압 $3 \mathrm{~m}$ Torr를 유 지하면서 증착하였다. $\mathrm{Ni}$ 및 $\mathrm{Ti}$ 층이 증착된 시편위에 $\mathrm{Cu}$ $(100 \mathrm{~nm})$ 를 $9 \times 10^{-7} \mathrm{Torr}$ 에서 $\mathrm{DC}$ 스퍼터로 증착하였다. $\mathrm{Ni}$ 및 $\mathrm{Cu}$ 의 두께를 각각 $20 \mathrm{~nm}, 100 \mathrm{~nm}$ 로 선정한 것은 MOSFET 공정을 모사하여 실시한 다른 연구들 ${ }^{4-6)}$ 을 고 려한 것이다. $\mathrm{Cu} / \mathrm{Ti} / \mathrm{Ni} / \mathrm{Si}$ 가 증착된 시편은 $10^{-5} \mathrm{Torr}$ 의 관 상로에서 $400^{\circ} \mathrm{C} 40$ 분간 열처리하여 $\mathrm{NiSi}$ 형성 및 $\mathrm{Cu}$ 의 확산 특성을 연구하였다. 이 열처리 조건은 $\mathrm{NiSi}$ 형성이 충분히 가능하면서도 Wang 등의 연구 ${ }^{1)}$ 에서 $\mathrm{TaN} / \mathrm{Cu} / \mathrm{NiSi}$ 접촉이 열적불안정성을 나타낸 $350^{\circ} \mathrm{C}$ 를 고려하여 선택하 였다. 비교하기 위하여 일부의 시편은 기존의 방법으로 제 작하였다. 즉, 기판위에 $\mathrm{Ni}$ 을 증착한 후 $\mathrm{N}_{2}$ 분위기에서 $500^{\circ} \mathrm{C} 100$ 초 single-step으로 급속열처리(Rapid Thermal Annealing, RTA)하여 $\mathrm{NiSi}$ 를 형성하고 ${ }^{2)}$ 미반응 $\mathrm{Ni}(8 \mathrm{~nm})$ 을 건식 에칭으로 제거하였다. 형성된 $\mathrm{NiSi}$ 위에 위와 동 일한 조건으로 $\mathrm{Ti}$ 및 $\mathrm{Cu}$ 를 증착한 후 관상로에서 열처 리하였다. 시편의 표면은 광학현미경 및 SPM (Scanning Probe Microscopy)으로 관찰하였으며, 조성 및 결정성은 XRD (X-Ray Diffractometry)로 조사하였으며, AES (Auger Electron Microscopy)에 의해 깊이에 따른 화학조성의 변 화를 분석하였다.

\section{3. 결과 및 고찰}

Fig. 1은 기존의 방법에 따라 $\mathrm{Si}$ 위에 $\mathrm{Ni}(20 \mathrm{~nm})$ 을 증착하고 $500^{\circ} \mathrm{C} 100$ 초 급속열처리하여 $\mathrm{NiSi}$ 를 형성한 시 편에 대한 $\mathrm{AES}$ 깊이 분석 결과이다. $\mathrm{Si}$ 과 $\mathrm{Ni}$ 의 원자비가 $1: 1$ 로 균일하게 나타나 $500^{\circ} \mathrm{C}$ 급속열처리에 의해 $30 \mathrm{~nm}$ 정도 두께의 전형적인 $\mathrm{NiSi}$ 가 형성되었음을 알 수 있다. 표면에 약간의 산소가 있으나 $\mathrm{NiSi}$ 층에는 없는 것으로 나 타났다.

Fig. 2는 $\mathrm{NiSi}$ 가 형성된 위 시편의 표면에 남아있는 미 반응 $\mathrm{Ni}$ 을 제거하고 그 위에 $\mathrm{Cu}(100 \mathrm{~nm})$ 를 증착하거나 (Fig. 2(a)), Ti 확산방지층 $(20 \mathrm{~nm})$ 을 증착한 후 $\mathrm{Cu}$ 를 증 착하고(Fig. 2(b)), 관상로에서 $400^{\circ} \mathrm{C} 40$ 분간 열처리한 시 편에 대한 $\mathrm{AES}$ 결과이다. $\mathrm{Ti}$ 중간층의 유무에 관계없이 $\mathrm{Cu}$ 층에 약 $40 \mathrm{at} . \%$ 의 많은 산소가 포획되어 있는 것으로 나타났다. 이는 $\mathrm{Cu}$ 의 산소 한계 고용도인 약 $15 \mathrm{wt} . \%$ 에 해당하는 것으로 관상로의 진공도 한계 때문에 열처리 과 정에서 흡입된 것이다. ${ }^{6,13)}$ 따라서, $\mathrm{Cu}$ 층에는 아래의 $\mathrm{XRD}$ 분석(Fig. 5)에서 확인되듯이 상당량의 산화물이 형성된 것 으로 판단된다. ${ }^{5)}$ 또한 $\mathrm{Ti}$ 중간층에도 산소가 $\mathrm{Ti}$ 보다 4 배나 더 많이 있는 것으로 나타났다. 이러한 과량의 산 소 포획은 $\mathrm{Ti}$ 의 산소친화력 때문에 나타나는 것으로 진 공로를 사용한 $\mathrm{Ti}^{13)}$ 과 $\mathrm{Ta}^{5}$ 확산방지층의 경우에도 나타 난다. 이 산소는 $\mathrm{Cu}$ 의 입계를 통해 $\mathrm{Ti}$ 층으로 확산한 것 이며 $\alpha-\mathrm{Ti}$ 외에 $\mathrm{Ti}$ 산화물을 형성하였을 것으로 생각된 다. 그런데, Yin 등의 연구 ${ }^{16)}$ 에 의하면 $\mathrm{Ta}$ 중간층의 산화 가 $\mathrm{Cu}$ 확산을 지연시키는 데 기여하는 것으로 보고된 바 있다. 확산방지층의 산소 포획 정도는 열처리 진공도는 물론, 산소 포획 능력이 큰 확산방지층의 상대적 두께, 즉 부피에 따라서도 달라진다.

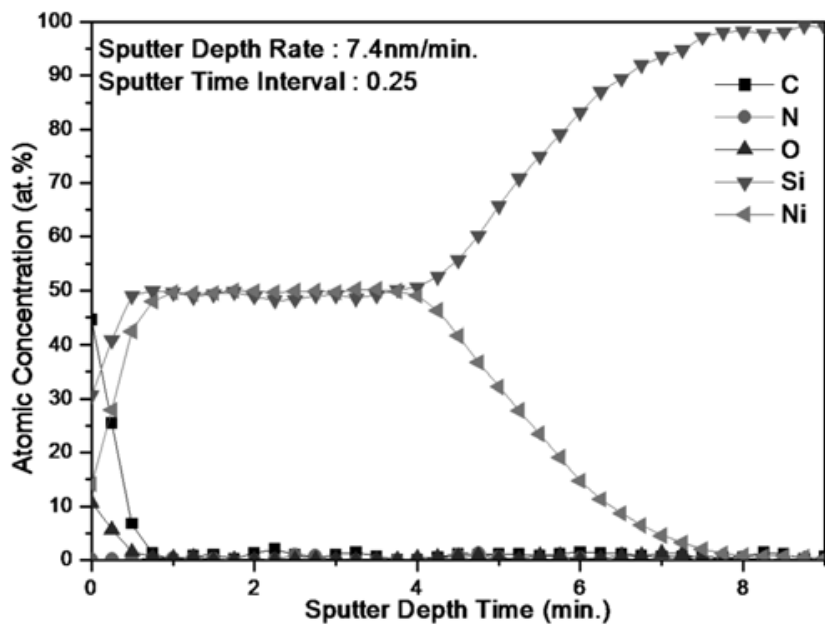

Fig. 1. AES depth profiles of $\mathrm{Ni} / \mathrm{Si}$, rapidly thermal-annealed (RTA) at $500^{\circ} \mathrm{C}$ for $100 \mathrm{sec}$. 


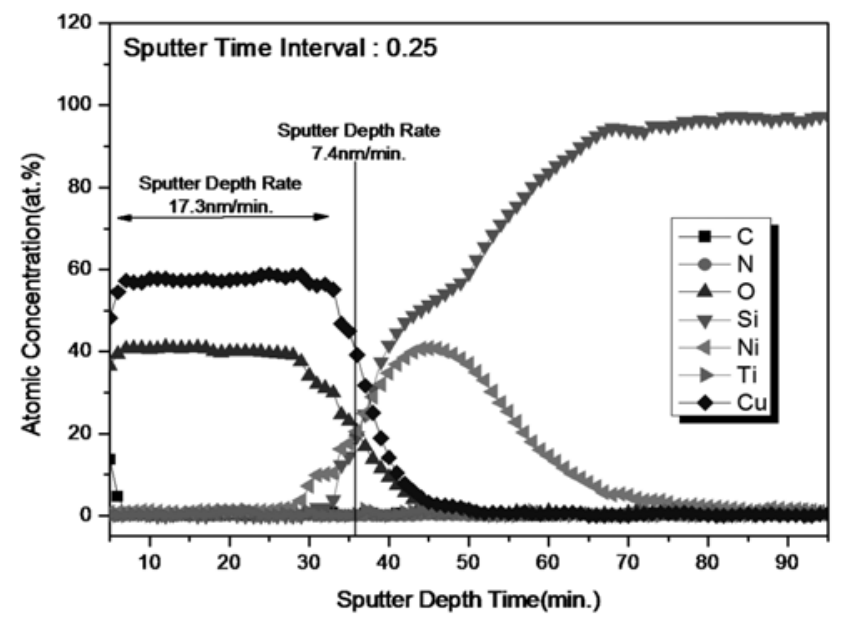

(a)

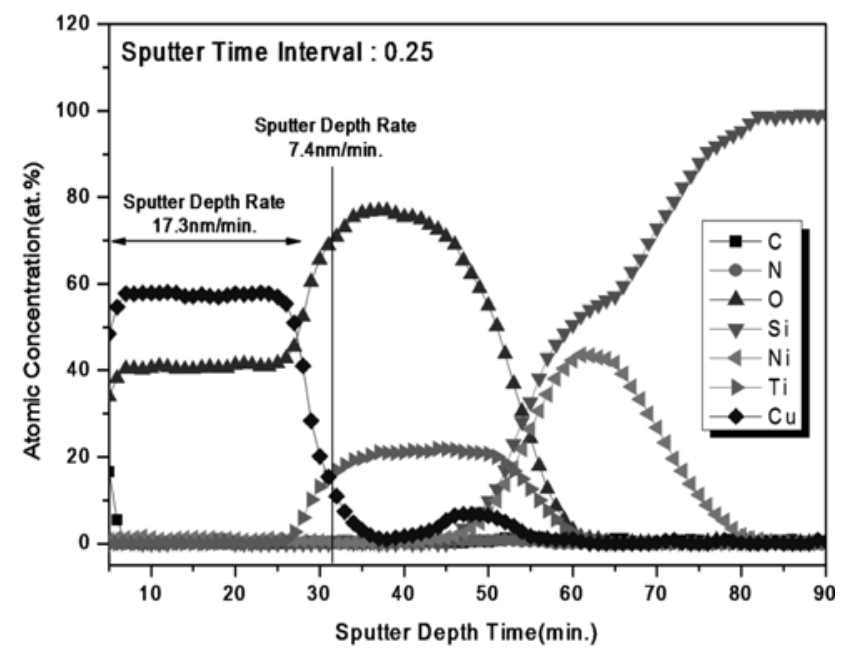

(b)

Fig. 2. AES depth profiles of (a) $\mathrm{Cu}(100 \mathrm{~nm}) / \mathrm{NiSi} / \mathrm{Si}$, and (b) $\mathrm{Cu}(100 \mathrm{~nm}) / \mathrm{Ti}(20 \mathrm{~nm}) / \mathrm{NiSi} / \mathrm{Si}$, furnace-annealed at $400^{\circ} \mathrm{C}$ for $40 \mathrm{~min}$.

한편 $\mathrm{Ti}$ 방지층의 유무와 관계없이 $1: 1$ 의 균일한 조 성비를 갖고 있던 $\mathrm{NiSi}$ 층은 붕괴되어 층간 경계가 불 분명해진 것으로 나타났다. 이는 열처리 과정에서 일 부 $\mathrm{NiSi}$ 층이 분해하고 $\mathrm{Ni}$ 이 확산하였기 때문이다. 그 결과 $\mathrm{Ti}$ 방지층이 없는 경우 $\mathrm{Cu}$ 와 $\mathrm{Ni}$ 이 상호 확산한 것 으로 나타났다(Fig. 2(a)). $\mathrm{Cu}-\mathrm{Ni}$ 이원계는 $\mathrm{Cu}$ 에 비해 $\mathrm{Ni}$ 이 100 배 이상 빨리 확산하고 전율고용체를 형성하므로 온도가 더 높거나 열처리 시간이 길면 완전 고용될 때 까지 상호 확산할 수 있다. $\mathrm{Cu}-\mathrm{Ni}$ 고용체는 $\mathrm{Ni}$ 함량에 비례하여 비저항이 증가하며, $\mathrm{Cu}$ 에 비해 $\mathrm{Ni}$ 의 비저항이 약 4배 높다. ${ }^{2)}$ 따라서, $\mathrm{Cu}-\mathrm{Ni}$ 고용체의 형성은 접촉의 비 저항을 증가시킨다. 또한, $\mathrm{Cu}$ 와 $\mathrm{Si}$ 도 상호확산하여 $\mathrm{Cu}$ 실 리사이드를 형성할 수 있다. ${ }^{17)}$ Wang 등의 연구 ${ }^{1}$ 에서도 $\mathrm{Cu}$ 가 $\mathrm{NiSi}$ 와 직접 접촉하여 있을 때는 $\mathrm{NiSi}$ 층으로 확산하 여 $\mathrm{Cu}_{3} \mathrm{Si}$ 를 형성하는 것으로 보고되었다. $\mathrm{NiSi}$ 의 분해 및 확산의 결과 $\mathrm{NiSi}$ 층에는 $\mathrm{Ni}$ 이 $\mathrm{Si}$ 보다 적어졌는데, $\mathrm{NiSi}_{2}$

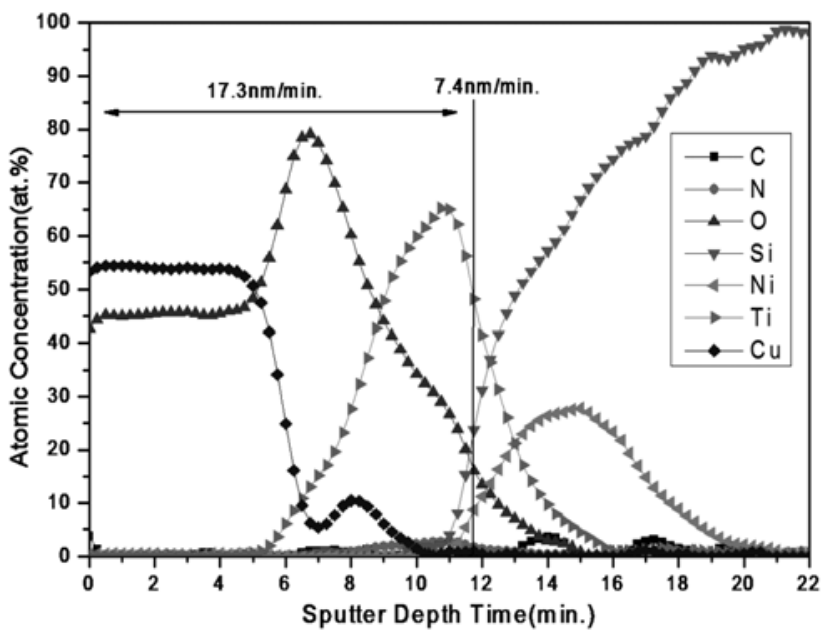

Fig. 3. AES depth profiles of $\mathrm{Cu}(100 \mathrm{~nm}) / \mathrm{Ti}(100 \mathrm{~nm}) / \mathrm{Ni}(20 \mathrm{~nm}) /$ $\mathrm{Si}$, furnace-annealed at $400^{\circ} \mathrm{C}$ for $40 \mathrm{~min}$.

는 $750^{\circ} \mathrm{C}$ 이상에서 형성된다는 것 ${ }^{9}$ 을 감안하면 일부 $\mathrm{NiSi}$ 가 $\mathrm{NiSi}_{2}$ 로 상변환한 것이 아니라 분해한 $\mathrm{Ni}$ 이 $\mathrm{Cu}$ 로 확 산되고 잉여 $\mathrm{Si}$ 이 남아 있기 때문으로 판단된다. 그런데 $\mathrm{Cu}$ 층으로의 확산한 $\mathrm{Si}$ 의 양은 $\mathrm{Ni}$ 보다는 작았다. 이는 $\mathrm{Cu}-$ $\mathrm{Si}$ 의 경우 $\mathrm{Cu}$ 가 주확산원소(dominant diffusing species)이 어서 $\mathrm{Si}$ 이 상대적으로 어렵기 때문이다. ${ }^{5)}$

반면 $\mathrm{Ti}$ 중간층이 있는 경우(Fig. 2(b)), $\mathrm{Cu}-\mathrm{Ti}$ 의 상호 확산은 상당히 억제되고 있음을 알 수 있다. 이는 $\mathrm{Cu}$ 가 $\mathrm{Ni}$ 과는 $250^{\circ} \mathrm{C}$ 이상이면 고용체를 형성할 수 있지만 $\mathrm{Ti}$ 와 는 고용율이 1.6 at.\%이하로 매우 낮아 혼합이 어렵기 때 문으로 해석할 수 있다. 한편, Ti-NiSi 계면에서는 Fig. 2(a)에서 보다는 작지만 어느 정도 혼합이 일어난 것으 로 나타났는데, 고용체의 형성과정으로 이해될 수 있다. $\mathrm{Ti}-\mathrm{Ni}$ 의 경우, $400^{\circ} \mathrm{C}$ 이하에서는 $\mathrm{Ni}$ 이 훨씬 더 빨리 확산 하여 비정질 혼합물을 형성하는 것으로 알려져 있다. 또 한, $\mathrm{Si}$ 도 $\mathrm{Ti}$ 층으로 확산한 것으로 나타났는데, $\mathrm{Ti}-\mathrm{Si}$ 이 원계에서는 $\mathrm{Si}$ 이 주확산원소이기 때문이다. 그런데, $\mathrm{Ti}$ 실 리사이드의 형성 온도가 $500^{\circ} \mathrm{C}$ 이상이고, 특히 $\mathrm{TiSi}_{2}$ 는 $750^{\circ} \mathrm{C}$ 이상에서 형성되므로 ${ }^{9)} \mathrm{Ti}-\mathrm{Si}$ 경계면에서도 혼합물 이 형성된 것으로 볼 수 있다. 그럼에도 불구하고 계면 에서의 혼합물 형성은 상당히 억제되어 $\mathrm{Cu}$ 접촉층, $\mathrm{Ti}$ 확산방지층, 및 $\mathrm{NiSi}$ 층의 계면이 명확하게 유지되었다.

Fig. 3은 기존의 방법과 달리하여 $\mathrm{NiSi}$ 형성 열처리과 정을 거치지 않고 $\mathrm{Ni}(20 \mathrm{~nm}) / \mathrm{Ti}(100 \mathrm{~nm}) / \mathrm{Cu}(100 \mathrm{~nm})$ 를 차례로 증착한 후 $400^{\circ} \mathrm{C} 40$ 분 한차례 열처리한 시편의 $\mathrm{AES}$ 분석 결과이다. Fig. 2(b)와 비교하여 $\mathrm{Ti}$ 중간층이 5 배 두꺼워 산소가 충분히 $\mathrm{Ti}$ 층으로 확산하지 못하였다. 그 결과 $\mathrm{Ti}$ 에 대한 산소 원자비는 전체적으로 $1: 1$ 로 낮 아졌지만 $\mathrm{Cu}$ 와 $\mathrm{Ti}$ 층 사이에 산소가 과다한 $\mathrm{Ti}$ 산화물 층 이 생겨난 것으로 나타났다. ${ }^{16)}$ 반면, $\mathrm{Cu}$ 층의 산소 함량 은 45 at.\%로 조금 더 증가하였다. 한편, $\mathrm{Ni}$ 과 $\mathrm{Si}$ 의 원자 


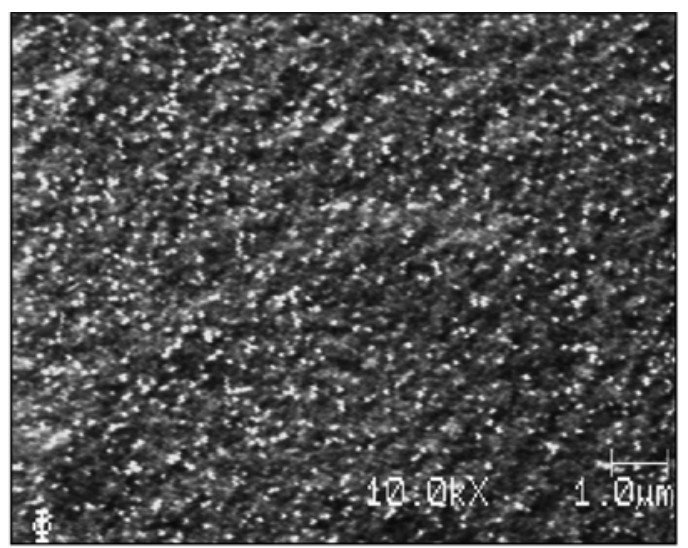

(a)

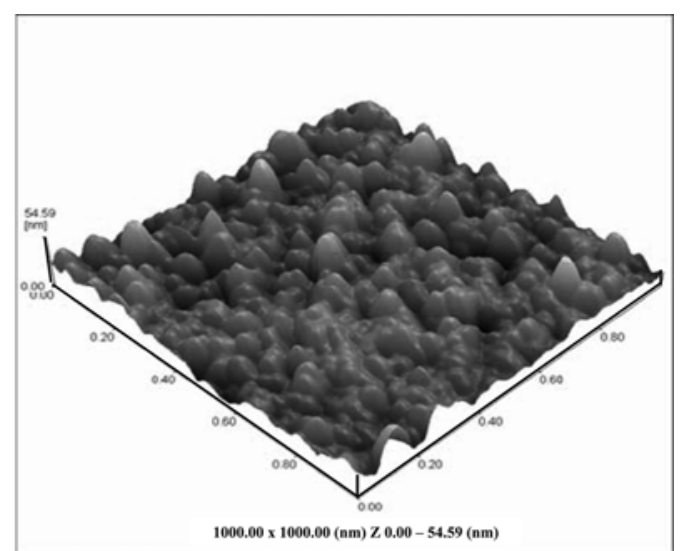

(b)

Fig. 4. (a) Optical and (b) $\mathrm{SPM}$ surfacial images of $\mathrm{Cu}(100 \mathrm{~nm}) / \mathrm{Ti}(100 \mathrm{~nm}) / \mathrm{Ni}(20 \mathrm{~nm}) / \mathrm{Si}$, furnace-annealed at $400^{\circ} \mathrm{C}$ for $40 \mathrm{~min}$.

비는 1:2 이상으로 균일한 $\mathrm{NiSi}$ 가 형성되지 못하였으며, $\mathrm{Ti}$ 과 $\mathrm{Ni}$ 및 $\mathrm{Si}$ 과의 상호확산이 상당 정도 진행된 것으로 나타났다. 위에서 언급한 바와 같이 $\mathrm{Ti}-\mathrm{Ni}$ 의 경우 $\mathrm{Ni}$ 이 확산하여 비정질 혼합물을 형성한다. 이와는 달리 $\mathrm{Cu}$ 는 $\mathrm{Ti}$ 층으로 거의 확산되지 않고 경계가 뚜렷한 $\mathrm{Cu}$ 층을 유지하고 있다. 또한 $\mathrm{Ti}$ 의 $\mathrm{Cu}$ 로의 확산도 미미하였다.

Fig. 4는 위 Fig. 3 시편의 $\mathrm{Cu}$ 표면층을 광학현미경과 $\mathrm{SPM}$ 으로 관찰한 결과이다. $\mathrm{Cu}$ 는 입자의 직경이 약 $50 \mathrm{~nm}$ 의 주상구조(columnar structure)이며 입자의 높이는 최대 $55 \mathrm{~nm}$ 로 $\mathrm{Cu}$ 박막 두께 $(100 \mathrm{~nm})$ 의 반 정도이었다. $\mathrm{Ti}$ 중 간층의 두께가 300 및 $500 \mathrm{~nm}$ 인 경우 입자는 박막의 두 께보다 크고 조야한 구형을 나타내어(데이터 미포함), 열 처리 온도가 높을 때 ${ }^{13)}$ 와 유사한 경향성을 보였다. 이러 한 $\mathrm{Cu}$ 의 응집은 $\mathrm{Ti}$ 산화층의 형성과 이로 인한 $\mathrm{Cu} / \mathrm{Ti}$ 층 간의 점착성(wettability) 감소와 관계가 있으며 면저항을 증가시킨다. ${ }^{5,6)} \mathrm{Fig} .4(\mathrm{a})$ 에 나타난 흰색 점들은 Fig. 5에 확인되는 바와 같이 열처리 과정에서 발생한 $\mathrm{Cu}$ 의 산화

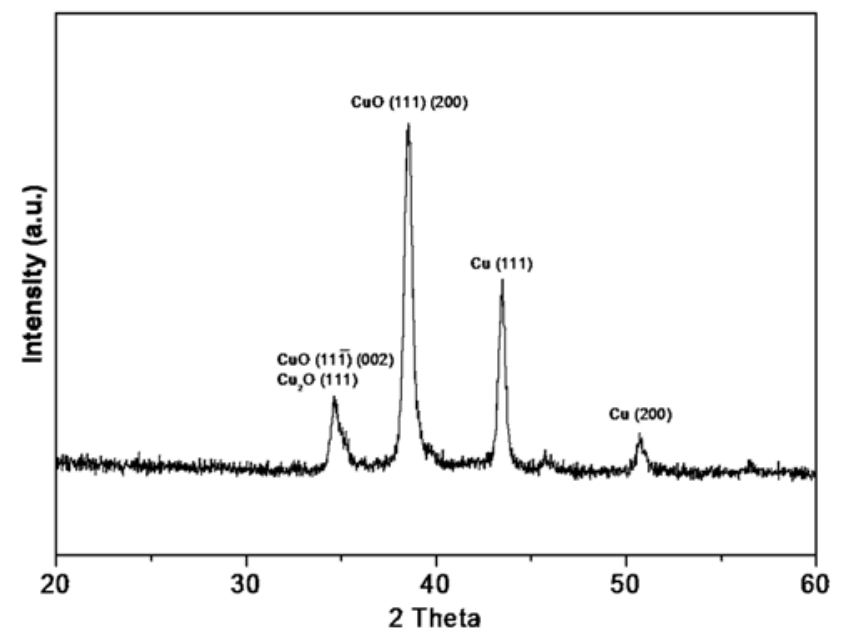

Fig. 5. XRD patterns of $\mathrm{Cu}(100 \mathrm{~nm}) / \mathrm{Ti}(100 \mathrm{~nm}) / \mathrm{Ni}(20 \mathrm{~nm}) / \mathrm{Si}$, furnace-annealed at $400^{\circ} \mathrm{C}$ for $40 \mathrm{~min}$.
와 $\mathrm{Cu}$ 산화물 형성에 의한 것이다.

Fig. 5 는 $\mathrm{Cu}$ 표면층에 대한 $\mathrm{XRD}$ 분석 결과이다. $\mathrm{CuO}$ (111) 피크가 가장 크게 나타났으며 $\mathrm{CuO}(-111)$ 은 $\mathrm{Cu}_{2} \mathrm{O}$ (111)과 겹쳐 있는 것으로 판단되어 형성된 산화물은 $\mathrm{Cu}_{2} \mathrm{O}$ 와 $\mathrm{CuO}$ 로 분석된다. ${ }^{18)} \mathrm{Fig}$. 3 의 $\mathrm{AES}$ 깊이 조성과 비교하면 이들 산화물은 별개의 층을 형성하였다기 보다 는 $\mathrm{Cu}$ 와 더불어 혼재하고 있는 것으로 생각된다. 한편, $\mathrm{Cu}$ 피크도 뚜렷히 나타났으나 $\mathrm{Cu}$ 와 $\mathrm{Ti}$ 및 $\mathrm{Ni}$ 과의 반응 에 의한 화합물 피크는 볼 수 없다. 따라서, 열처리 과 정에서 $\mathrm{Cu}$ 의 산화 외에 다른 반응은 일어나지 않는 것 으로 확인된다. $\mathrm{Cu}(111)$ 피크가 우세한 것은 증착한 $\mathrm{Cu}$ 박막에서 일반적으로 나타나는 우선 배향(texture) 때문 이다. ${ }^{13,18)}$

Fig. 3-4에서 $\mathrm{Cu} / \mathrm{Ti} / \mathrm{Ni} / \mathrm{Si}$ 다층을 열처리하여 $\mathrm{NiSi}$ 접 촉과 $\mathrm{Cu}$ 플러그를 동시에 형성할 경우 $\mathrm{Cu}$ 는 $\mathrm{Ti}$ 에 의해 확산이 방지되어 뚜렷한 계면을 유지하였지만 $\mathrm{NiSi}$ 형 성이 불완전한 것으로 나타났다. 다층 박막의 경우 열처 리 온도 및 시간 외에도 박막의 상대적인 두께가 상호확 산 및 반응에 영향을 미친다. 일반적으로 MOSFET 소자 의 확산방지층의 두께는 $15 ~ 20 \mathrm{~nm}$ 이지만, ${ }^{4-6)} 5 \mathrm{~nm}$ 인 경우 에도 $\mathrm{Cu}$ 확산에는 효과적인 것 ${ }^{11)}$ 으로 보고된 바 있다. 이 를 고려하여 $\mathrm{Cu}(100 \mathrm{~nm})$ 및 $\mathrm{Ni}(20 \mathrm{~nm})$ 의 두께는 유지하 고 $\mathrm{Ti}$ 확산방지층의 두께를 변화하여 Fig. 1 에서와 같은 조성의 $\mathrm{NiSi}$ 형성을 시도하였다. Fig. 6은 $\mathrm{Ti}$ 두께가 각 각 $50,20,10 \mathrm{~nm}$ 인 경우의 $\mathrm{AES}$ 깊이 분석 결과이다. $\mathrm{Ti}$ 두께가 $50 \mathrm{~nm}$ 인 경우(Fig. 6(a)), Fig. 3 의 $100 \mathrm{~nm}$ 인 경 우와 별 차이를 보이지 않았다. 그러나, $\mathrm{Ni}(20 \mathrm{~nm})$ 과 같 이 $\mathrm{Ti}$ 두께가 $20 \mathrm{~nm}$ 인 경우(Fig. 6(b)), 산소가 $\mathrm{Ti}$ 중간층 에 균일한 조성으로 포획되고, 그 밑에는 원자비가 거의 $1: 1$ 인 층이 뚜렷이 형성된 것으로 나타났다. 이는 기존 의 방법으로 $\mathrm{NiSi}$ 를 형성하고 그 위에 $\mathrm{Cu}$ 를 증착한 후 열처리한 Fig. 2(b)와 거의 동일한 결과이다. 이로 미루어 


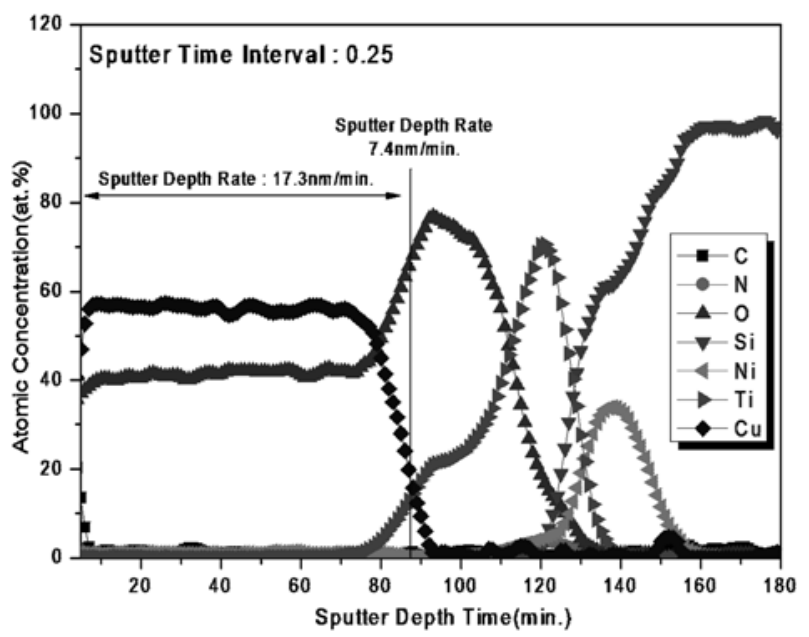

(a)

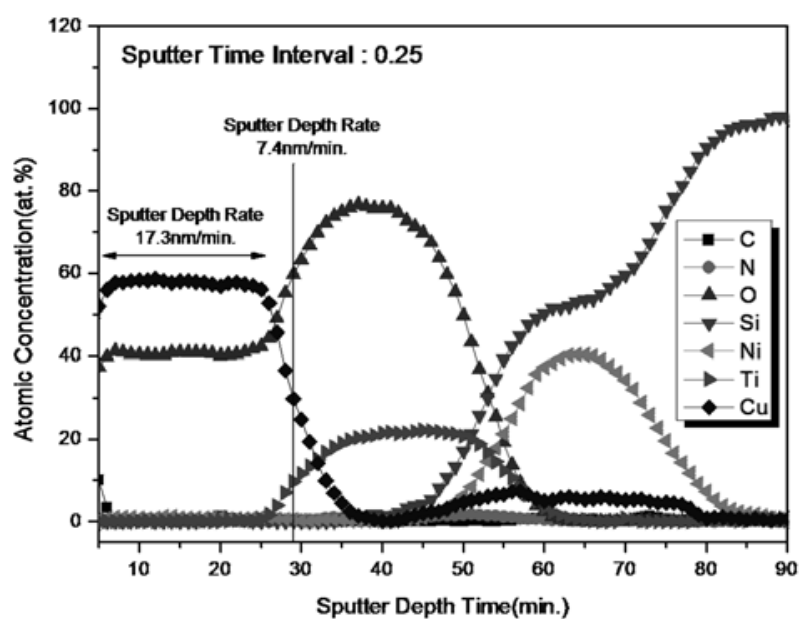

(b)

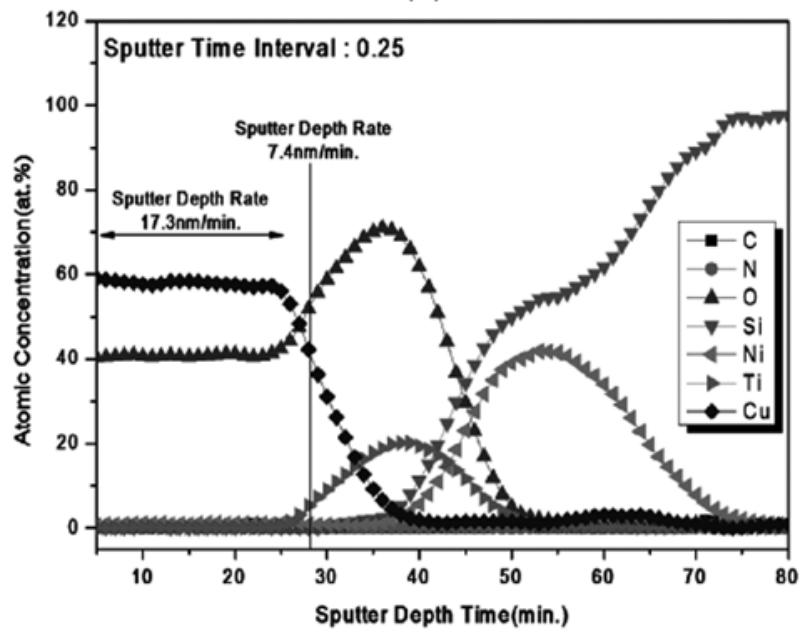

(c)

Fig. 6. AES depth profiles of the $\mathrm{Cu}(100 \mathrm{~nm}) / \mathrm{Ti} / \mathrm{Ni}(20 \mathrm{~nm}) / \mathrm{Si}$, furnace-annealed at $400^{\circ} \mathrm{C}$ for $40 \mathrm{~min} .$. : (a) $\mathrm{Ti}(50 \mathrm{~nm})$, (b) $\mathrm{Ti}(20 \mathrm{~nm})$ and (c) $\operatorname{Ti}(10 \mathrm{~nm})$.

, 투과전자현미경(TEM) 등으로 확인이 필요하지만 이 층 에는 주로 $\mathrm{NiSi}$ 가 형성된 것으로 판단된다. Fig. 2(b)에 비
해 약간 다른 점은 열처리 과정에서 $\mathrm{Si}$ 이 보다 많이 $\mathrm{Ti}$ 층으로 확산하고 그 결과 $\mathrm{NiSi}$ 층의 $\mathrm{Si}$ 원자비가 조금 더 높게 나타난 것이다. 한편, $\mathrm{Ti}$ 두께가 $10 \mathrm{~nm}$ 인 경우(Fig. 6(c))도 $20 \mathrm{~nm}$ 인 경우와 유사하였으나 $\mathrm{Si}$ 의 $\mathrm{Ti}$ 층으로의 확산이 줄어들어 $\mathrm{NiSi}$ 층의 원자비가 더 $1: 1$ 에 가까워진 것으로 나타났다. 이로 미루어, $\mathrm{Ti}$ 확산방지층의 두께를 $\mathrm{Ni}$ 층보다 같거나 얇게 한 경우, $1: 1$ 원자비에 가까운 $\mathrm{NiSi}$ 와 계면이 뚜렷이 구별되는 $\mathrm{Cu}$ 플러그 및 $\mathrm{Ti}$ 확산 방지층을 형성할 수 있는 것으로 나타났다.

다층 금속 박막에서는 벌크 재료에는 나타나지 않는 여 러 가지 복잡한 상호 반응이 일어날 수 있다. 본 연구에 서는 $\mathrm{Cu} / \mathrm{Ti} / \mathrm{Ni} / \mathrm{Si}$ 다층박막을 $400^{\circ} \mathrm{C}$ 에서 열처리하였다. 이 때 $\mathrm{Cu} / \mathrm{Ti}$ 의 계면에서는 상호 반응이 억제되어, $\mathrm{Cu}$ 층은 증착된 그대로의 형태를 유지하였다. 반면, $\mathrm{Ni} / \mathrm{Si}$ 의 계면 에서는 $\mathrm{Si}$ 이 급속히 확산하여 $\mathrm{NiSi}$ 접촉을 형성하였고, 일 부분은 $\mathrm{Ti}$ 층으로 까지 확산하였으나 $\mathrm{Ti}$ 혼합물의 형성 은 매우 제한적이었다. 또한 $\mathrm{Ti} / \mathrm{Ni}$ 의 계면에서의 혼합물 형성도 억제되어, $\mathrm{Cu}$ 플러그, $\mathrm{Ti}$ 확산방지층이 뚜렷히 구 분되게 형성된 것으로 나타났다. 이상의 결과에서, $\mathrm{Si}$ 기 판위에 $\mathrm{Cu} / \mathrm{Ti} / \mathrm{Ni}$ 을 차례로 증착하고 열처리하면 $\mathrm{NiSi}$ 접 촉이 형성됨과 동시에 $\mathrm{Ti}$ 확산방지층과 $\mathrm{Cu}$ 플러그를 형 성시킬 수 있음을 확인하였다. 열처리 과정에서 문제점 으로 나타난 산화를 줄이고 열처리 온도와 시간을 조절 한다면 더 효과적인 접촉/플러그 형성 공정이 개발될 수 있을 것으로 생각된다.

\section{4. 결 론}

$\mathrm{Cu}$ 는 소자 상층부의 $\mathrm{Cu}$ 배선에는 물론, 기저층의 소스 및 드레인에서도 $\mathrm{Cu}$ 플러그 재료로서의 적용이 시도되고 있다. 한편, $\mathrm{NiSi}$ 는 고집적 소자의 게이트 및 소스/드레 인의 접촉 재료로 사용되어 왔다. 이때 $\mathrm{Cu}$ 를 플러그 재 료로 적용하려면 확산방지층이 필요하며 주로 $\mathrm{Ta}, \mathrm{TaN}$ 및 $\mathrm{Ru}$ 등이 고려되어 왔다. 그리고, $\mathrm{Cu}$ /확산방지층 $/ \mathrm{NiSi} / \mathrm{Si}$ 구조를 형성할 때, 기존에는 $\mathrm{Ni}$ 을 $\mathrm{Si}$ 기판에 증착한 후 $\mathrm{NiSi}$ 를 형성하고 그 위에 확산방지층과 $\mathrm{Cu}$ 플러그를 순 차적으로 증착하는 방법을 취하였 다. 본 연구에서는 $\mathrm{Ti}$ 을 확산 방지 재료로 선택하였고, 기존의 방법과 달리 하여 $\mathrm{Si}$ 기판위에 $\mathrm{Ni}, \mathrm{Ti}, \mathrm{Cu}$ 를 차례로 증착한 후 한 번의 열처리로 $\mathrm{NiSi}$ 접촉 및 $\mathrm{Ti}$ 확산방지층과 $\mathrm{Cu}$ 플러 그를 동시에 형성하는 공정을 시도하였다. $\mathrm{Cu}(100 \mathrm{~nm})$ / $\mathrm{Ti} / \mathrm{Ni}(20 \mathrm{~nm}) / \mathrm{Si}$ 다층박막을 $\mathrm{Ti}$ 의 두께를 달리하여 증착 한 후 $400^{\circ} \mathrm{C}$ 에서 30 분간 열처리하였다. $\mathrm{Ti}$ 층의 두께가 $\mathrm{Ni}$ 층과 같이 $20 \mathrm{~nm}$ 및 그 이하인 경우, $\mathrm{Cu} / \mathrm{Ti}$ 의 계면 에서의 상호반응은 억제되었고, $\mathrm{Ni} / \mathrm{Si}$ 의 계면에서는 $\mathrm{Si}$ 이 급속히 확산하여 $\mathrm{NiSi}$ 를 형성하였다. 이는 기존의 방법으 
로 $\mathrm{NiSi}$ 를 형성하고 그 위에 $\mathrm{Cu}$ 를 증착한 후 열처리한 경우와 거의 동일한 결과이었다. 이로 부터, $\mathrm{Si}$ 기판위에 $\mathrm{Cu} / \mathrm{Ti} / \mathrm{Ni}$ 을 차례로 증착하고 열처리하면 $\mathrm{NiSi}$ 접촉이 만 들어짐과 동시에 $\mathrm{Ti}$ 확산방지층과 $\mathrm{Cu}$ 플러그를 형성할 수 있음을 확인하였다.

\section{참 고 문 헌}

1. C. -C. Wang, H. -H. Lin and M. -C. Chen, Jpn. J. Appl. Phys., 43, 5997 (2004).

2. J. -J. You and K. -S. Bae, Kor. J. Mater. Res., 17(9), 463 (2007) (in Korean).

3. C. Zhao, Zs. Tokei, A. Haider and S. Demuynck, Microelectron. Eng., 84, 2669 (2007).

4. C. Zhao, J. Y. Ahn, N. Horiguchi, S. Demuynck and Zs. Tokei, Microelectron. Eng., 85, 2009 (2008).

5. M. Zhou, Y. Zhao, W. Huang, B. -M. Wang, G. -P. Ru, Y. -L. Jiang, R. Liu and X. -P. Qu, Microelectron. Eng., 85, 2028 (2008).

6. J. -H. Lin, J. -H. Lee, C. -S. Hsu and J. -S. Fang, J. Electron. Mater., 38(11), 2251 (2009).

7. A. Lauwers, J. A. Kittl, M. J. H. Van Dal, O. Chamirian, M. A. Pawlak, M. de Potter, R. Lindsay, T. Raymakers, X. Pages, B. Mebarki, T. Mandrekar and K. Maes, Mater.
Sci. Eng. B, 114-115, 29 (2004).

8. K. Yoon and O. Song, Kor. J. Mater. Res., 18(1), 5 (2008) (in Korean).

9. H. Iwai, T. Ohguro and S. -I. Ohmi, Microelectron. Eng., 60, 157 (2002).

10. W. L. Yang, W. -F. Fa, H. C. You, K. -L. Ou, T. F. Lei and C. -P. Chou, IEEE T. Electron. Dev, ED-49(11), 1947 (2002).

11. F. Braud, J. Torres, J. Palleau, J. L. Mermet and M. J. Mouche, Appl. Surf. Sci., 91, 251 (1995).

12. M. Spindler, S. B. Menzel, C. Eggs, J. Thomas, T. Gemming and J. Eckert, Microelectron. Eng., 85, 2055 (2008).

13. S. Lee and J. Lee, Kor. J. Mater. Res., 14(4), 246 (2004) (in Korean).

14. D. Z. Chi, D. Mangelinck, A. Z. Zuruzi, A. S. W. Wong and S. K. Lahiri, J. Electron. Mater., 30(12), 1483 (2001).

15. Y. Setiawan, P. S. Lee, C. W. Tan and K. L. Pey, Thin Solid Films, 504, 153 (2006).

16. K. -M. Yin, L. Chang, F. -R. Chen, J. -J. Kai, C. -C. Chiang, P. Ding, B. Chin, H. Zhang and F. Chen, Thin Solid Films, 388, 15 (2001).

17. N. Mattoso, J. Mater. Sci., 30, 3242 (1995).

18. W. Gao, H. Gong, J. He, A. Thomas, L. Chan and S. Li, Mater. Lett., 51, 78 (2001). 